Reprod. Nutr. Dévelop., 1982, 22 (1 B), 201-208.

\title{
Influence of altered thyroid and nutritional states on early histogenesis of the rat cerebellar cortex with special reference to synaptogenesis
}

\author{
Christiane LEGRAND, J. CLOS, J. LEGRAND \\ Laboratoire de Physiologie comparée, \\ Université des Sciences et Techniques du Languedoc, 34060 Montpellier Cedex, France.
}

\begin{abstract}
Summary. On day of birth, the synaptic density of the rat cerebellar cortex in experimental, as compared to control, rats was slightly reduced or increased, respectively, after propylthiouracil treatment of the dam or thyroxine injection of the fetus. The stimulation of synaptogenesis in thyroxine-treated neonates was particularly obvious at the level of the ganglionic layer containing Purkinje cell bodies and was accompanied at the same level by accelerated growth of the presynaptic endings and perisomatic processes of the Purkinje cells. Undernourishment of the dam from day 6 of gestation led to an unexpected stimulation of synaptogenesis in the cerebellar cortex of the neonates; synaptic density was significantly increased above the normal value and much more markedly than in the thyroxine-treated neonates, but there was no abnormal proliferation of the neuronal processes. Different mechanisms underlay the transient stimulation of synaptogenesis in these two conditions. These results have been felated to the disturbances in the development of Bergmann glia previously found soon after birth in altered thyroid and nutritional states.
\end{abstract}

\section{Introduction.}

It has already been shown that the morphological and biochemical development of cerebellar Bergmann glial cells is retarded during the early postnatal period in young rats made hypothyroid by treating their dam with propylthiouracil ; on the contrary, this development is transiently accelerated in those given excess thyroxine from birth. The maturation of Bergmann astrocytes is also temporarily accelerated in the offspring of dams undernourished from day 6 of gestation (Clos et al., 1979, 1980 a, b ; Legrand et al., 1980). In the present work, the effects on synaptogenesis in the cerebellar cortex of congenital thyroid deficiency, thyroxine treatment of the fetus and undernourishment of the dam were investigated in newborn rats on day of birth. 


\section{Material and methods.}

Animals. - Wistar strain rats were used. Thyroid deficiency was induced in the newborns by treating the dams with $50 \mathrm{mg} /$ day of propylthiouracil (PTU) given by gastric intubation from day 17 of gestation. On day 18, another group of pregnant rat fetuses was given one subcutaneous injection of $20 \mu \mathrm{g}$ of $\mathrm{D}-\mathrm{L}$ thyroxine in a $25-\mu$ l suspension of $9 \mathrm{p}$. $100 \mathrm{NaCl}$. A third group of pregnant rats was undernourished by reducing the normal diet by 50 p. 100 from day 6 of gestation. The duration of gestation was carefully controlled and the newborns were always killed a few hours after parturition.

Electron microscopic methods. - The cerebella were immersed for $2 \mathrm{~h}$ in a $0.04 \mathrm{M}$ cacodylate-buffered solution ( $\mathrm{pH}$ 7.4) containing 1 p. 100 paraformaldehyde, 2 p. 100 glutaraldehyde and $0.2 \mathrm{mM} \mathrm{CaCl}_{2}$ and then postfixed in a cacodylate-buffered solution containing $2 \mathrm{p}$. $100 \mathrm{OsO}_{4}$. The cerebella were cut midsagittally, and each half was dehydrated and embedded in araldite. Midsagittal semithin sections of the vermis were stained with toluidine blue in order to check the correct orientation of the sections and the localization of the primary fissure. Ultrathin midsaggital sections of portions of the vermis around the primary fissure were then contrasted with lead citrate and uranyl acetate and observed with a JEM $100 \mathrm{~B}$ electron microscope. Electron micrographs (final magnification : $\times 20000)$ were made of large areas $\left(25000 \mu \mathrm{m}^{2}\right.$ in each group of animals) centered on the ganglionic layer and including the future molecular and inner granular layers. Three or four animals per group (control, PTU-treated, thyroxine-treated and offspring of underfed dams) were studied. All the well-identified synapses, i.e. all those displaying pre- and postsynaptic membrane specializations, the synaptic space and at least three presynaptic vesicles with a diameter of about 40 $\mathrm{nm}$ were counted in the electron micrographs. Even though we did not consider statistical analyses entirely appropriate to such studies because of the sampling problems inherent in electron microscopy, the results were statistically analyzed by Student's t-test. In any case, counting the synapses was helpful in confirming our numerous qualitative observations.

\section{Results.}

First of all, this study confirmed that synapses were present at birth in the rat cerebellar cortex (Del Cerro and Snider, 1972 ; Rebière, 1975 ; West and Del Cerro, 1976). They were scattered over the entire thickness of the cortex, except the outer germinative layer (figs. 1,2), but were more numerous around large cell

FIG. 1-2. - The cerebellar cortex of neonate rat.

FIG. 1. - Upper part of the molecular layer. Three axon terminals are seen making synapses (arrows) with the same postsynaptic element near an outer granule cell $(\mathrm{Gc})(\times 26000)$.

FIG. 2. - Lower part of the ganglionic layer. On the left, an axosomatic synapses; on the right, an axodendritic synapse (arrows) $(\times 13,500)$. 


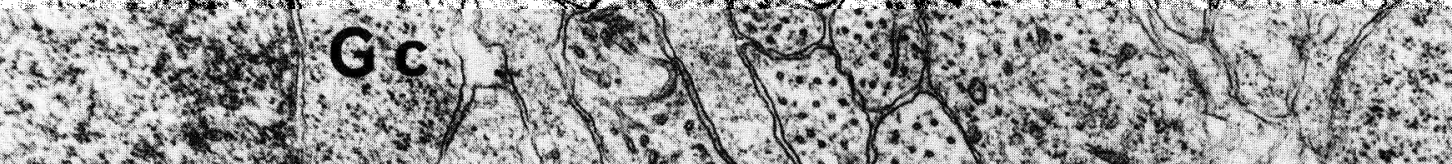

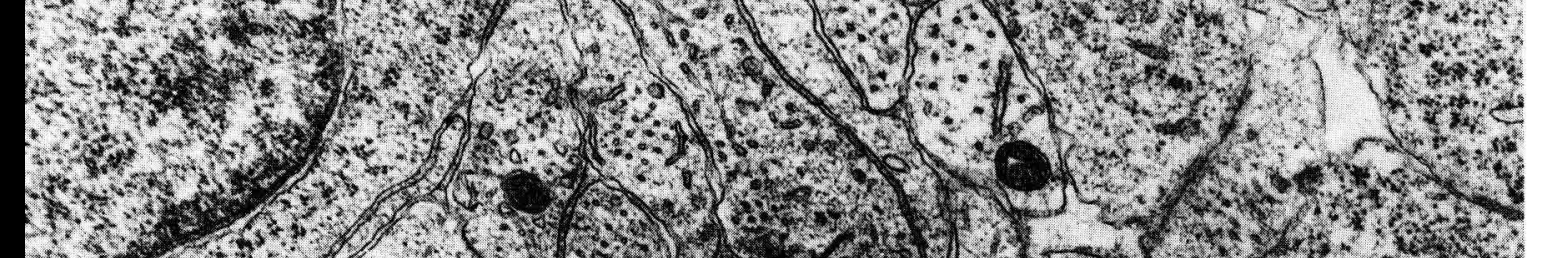

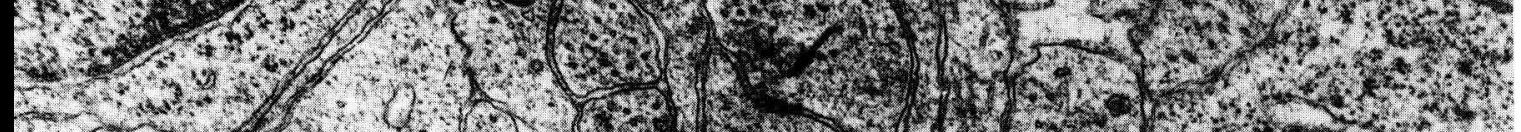

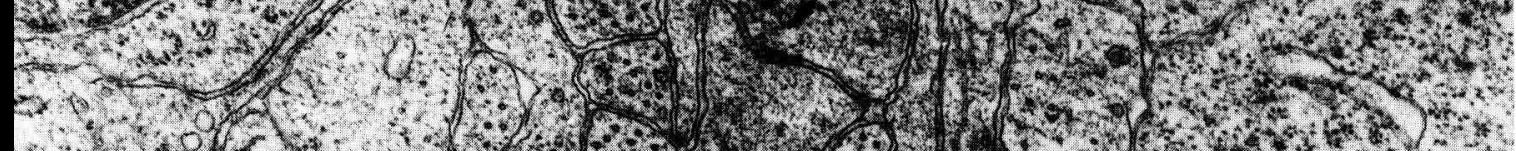

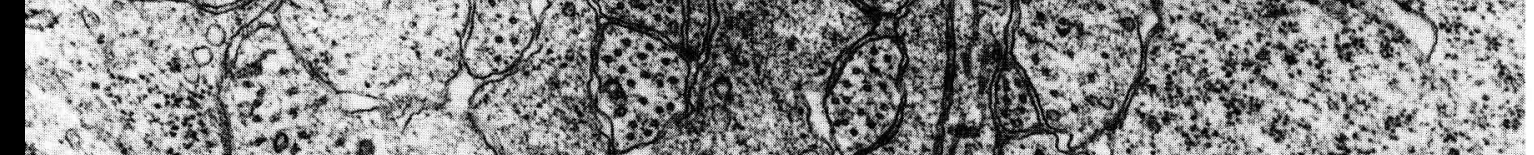

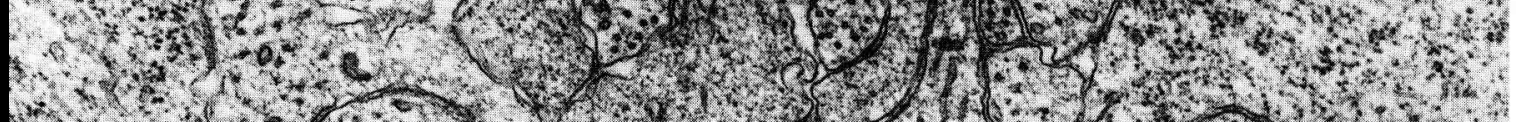

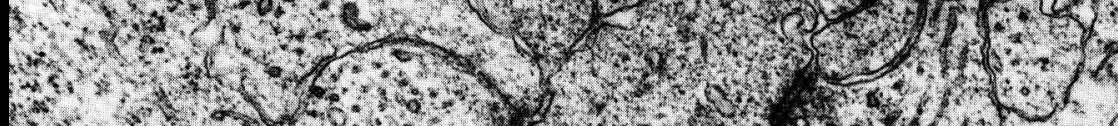

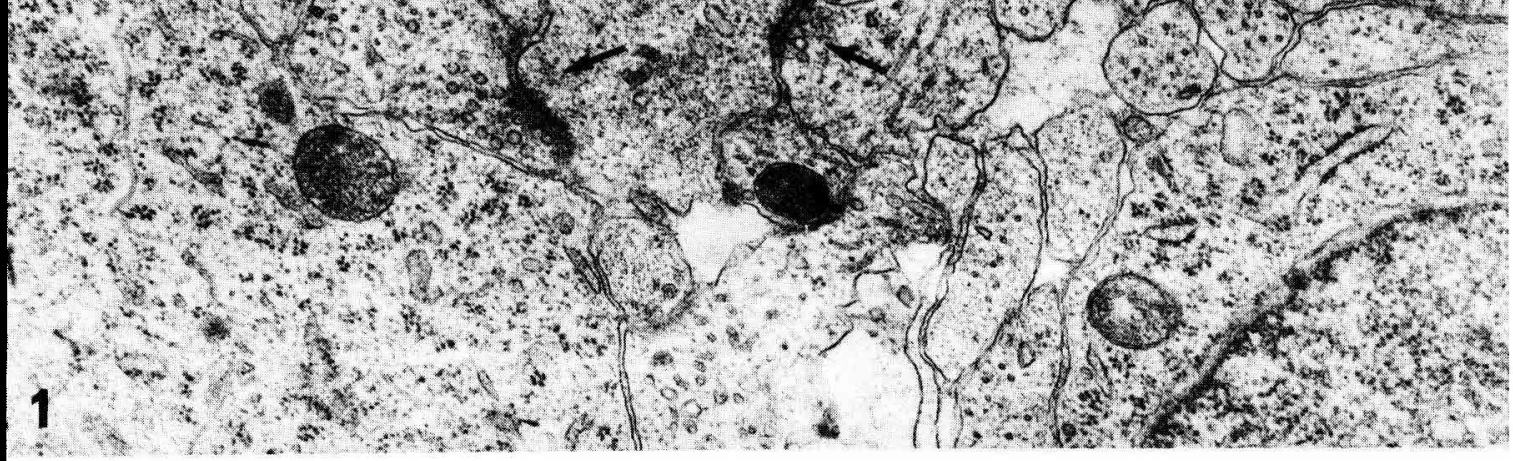

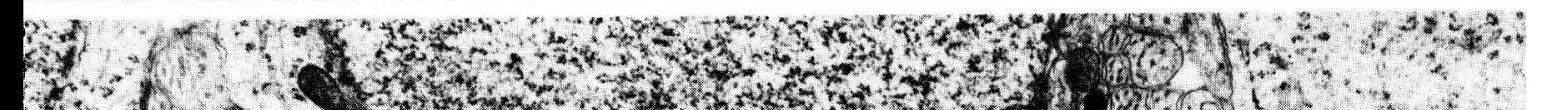

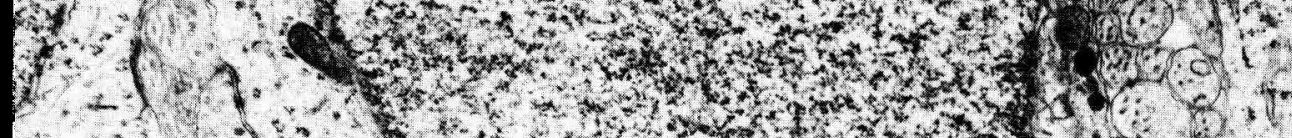

B.

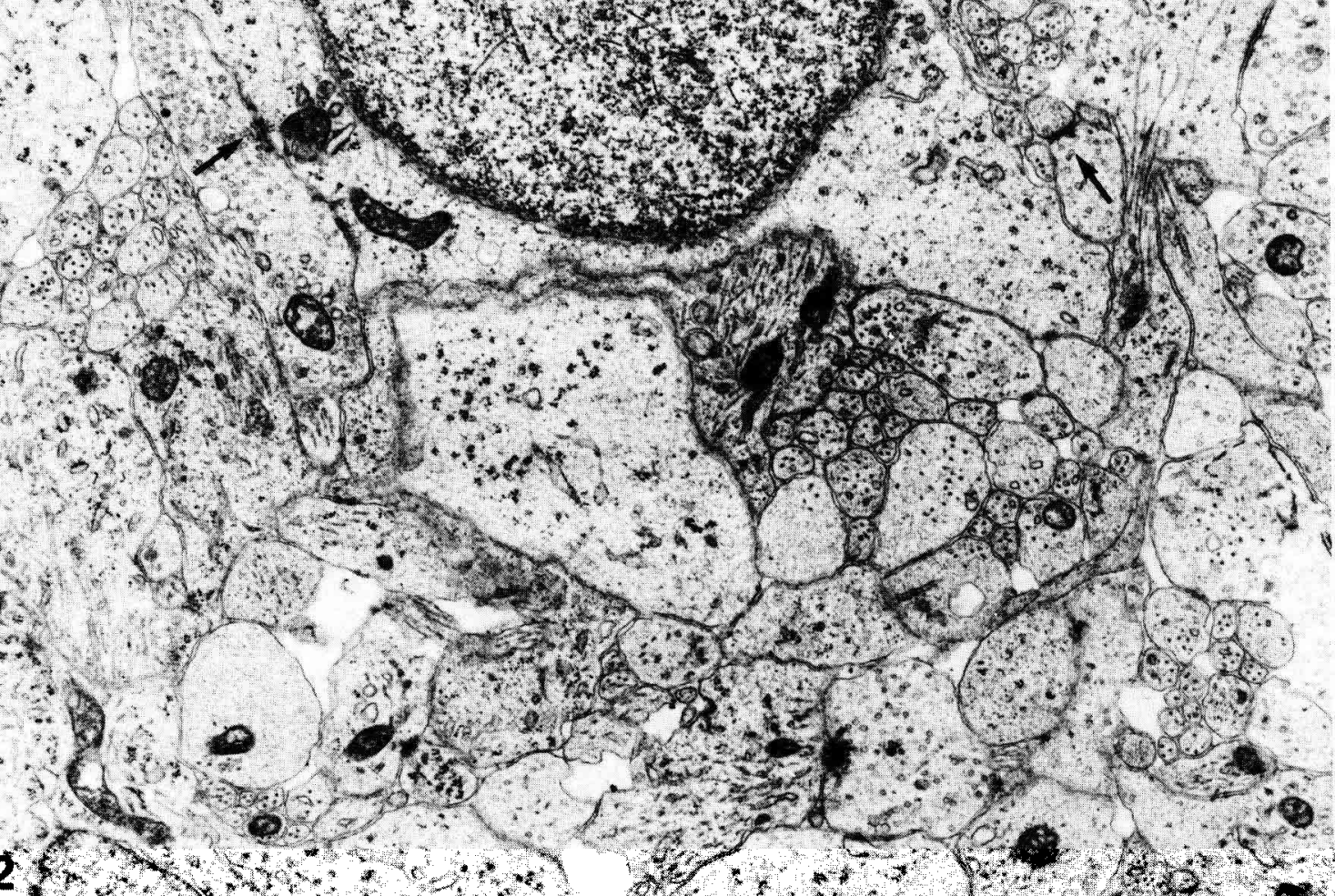


bodies with indented nuclei in the ganglionic layer containing Purkinje cell bodies. These synapses were either axosomatic or axodendritic. The exact nature of the structures making synapse could not be determined with certitude and so the synapses were difficult to characterize. Most of them, however, were clearly asymmetrical, and the presynaptic elements contained a small number of either polymorphous or round vesicles (figs. 3,4 ).

The ganglionic layer in PTU-treated newborn rats could not be delineated so well as in the controls. The tendency of the Purkinje cells to concentrate in this layer was less obvious. As previously reported by Rebière (1975), synaptic density was slightly less than normal but the difference with the control values was not significant (fig. 11). The structural specializations forming the synapses were not apparently different from the normal ones (figs. 5, 6).

Conversely, in newborn rats given thyroxine in utero, the limits of the ganglionic layer were more conspicuous than in the controls. Although synaptic density was slightly, but not significantly, increased as compared to the normal value, it was significantly higher than the hypothyroid value (fig. 11). Thyroid hormone appeared to have already had a slight stimulating effect on synaptogenesis. There were more large areas of clear cytoplasm in the ganglionic layer of thyroxine-treated newborn rats than in the controls and the thyroiddeficient animals and they often contained growth cone vesicles (Del Cerro and Snider, 1968). Some of them contained synaptic vesicles and therefore were axon terminals or varicosities; others might be sections of Purkinje cell perisomatic processes. The stimulation of synaptogenesis under the effect of the hormone was therefore accompanied by accelerated growth of the neuronal processes which was particularly evident at the level of the ganglionic layer. Synaptic configuration was apparently normal (figs. 7, 8).

The ganglionic layer in newborns from undernourished dams could be more easily delineated than in the controls and its synaptic density was significantly increased above the normal value (fig. 11). Consequently, the stimulation of synaptogenesis was more obvious than in the thyroxine-treated newborns. On the other hand, it was not accompanied by proliferation of cytoplasm sections or nerve endings in the ganglionic layer. It thus appeared that undernourishment of

FIG. 3-10. - Configuration of the synapses in the cerebellar cortex of neonate rat $(\times 29000)$.

FIG. 3-4. - Normal animals. Synapses in the molecular layer (fig. 3) and the ganglionic layer (fig. 4).

FIG. 5-6. - PTU-treated animals. Axosomatic synapse on a putative Purkinje cell body in the ganglionic layer (fig. 5). Axodendritic synapse in the ganglionic layer (fig. 6).

FIG. 7-8. - Thyroxine-treated animals. Axodendritic synapses in the inner part of the ganglionic layer (fig. 7) and the molecular layer (fig. 8).

FIG. 9-10. - Offspring of undernourished dams. Axosomatic synapse in the inner part of the molecular layer (fig. 9). Axodendritic synapse in the upper part of the molecular layer (fig. 10). 
the dam led to an increase in the number of synapses established between the pre-existing pre- and postsynaptic elements. The configuration of synapses appeared to be normal (figs. 9, 10).

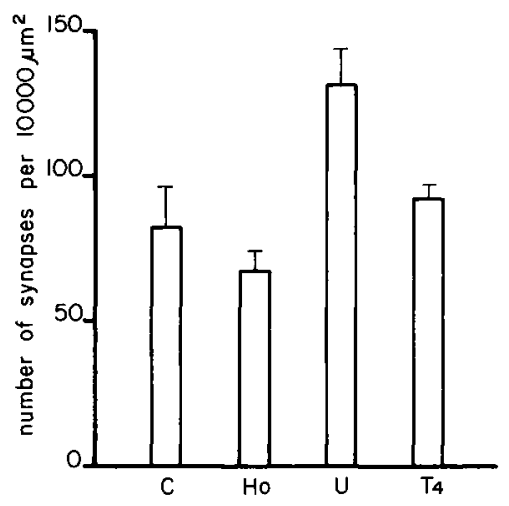

FIG. 11. - Synaptic density in the cerebellar cortex of neonate control rat $(\mathrm{C})$ and effect of hypothyroidism (Ho), thyroxine treatment of the fetus (T4) and undernourishment of the dam (U) on this density. Means \pm SEM. Three or four animals were studied in each experimental group. Significance of the differences (Student's t-test): C-Ho: ns ; C-T4 : ns ; $\mathrm{C}-\mathrm{U}: \mathrm{P}<0.05 ; \mathrm{T} 4-\mathrm{U}: \mathrm{P}<0.05$.

\section{Discussion.}

Analysis of synaptogenesis in the rat cerebellar molecular layer during the postnatal period (second postnatal week and later) has strongly suggested that thyroid hormone mainly controls the rate of synaptogenesis by stimulating axonal and dendritic growth rather than by interacting with synaptogenic events directly (Hajós et al., 1973 ; Lauder, 1978 ; Vincent, 1981).

On day of birth, the cross-sectional area of the cerebellar cortex around the primary fissure (measured in midsaggital sections of the cerebellum) was not significantly changed in the experimental conditions studied here (results not reported). Thus, the modifications in synaptic density observed reflect changes in the total number of synapses in that part of the cerebellar cortex. The present study therefore confirms that thyroxine has a stimulating effect on synaptogenesis ; furthermore, it shows that this effect is already evident at birth when the hormone is given to the fetus during late gestation. To our knowledge, except for the action of thyroid hormone on the histological structure of fetal bone (Legrand, 1969), these data constitute the most precocious morphogenetic effect of thyroid hormone to be reported during development in the rat. This early stimulation of synaptogenesis is associated with an augmentation in the density of nerve terminals, indicating again that it is probably mediated by an acceleration of neurite outgrowth.

Underfeeding the rat dam from day 6 of gestation leads to an unexpected stimulation of synaptogenesis in the cerebellar cortex of the newborn. This might account for the increased locomotor and exploratory activity observed in these animals, particularly during competition for milk. As pointed out above, the mechanisms underlying the early stimulation of synaptogenesis after undernourishment of the dam and thyroxine treatment of the fetus are probably 
different. Although undernutrition may modify the endocrine balance, thyroid function does not appear to be markedly affected by undernourishment during the neonatal period (Vigouroux, 1974). However, it is not impossible that undernourishment of the dam and hyperthyroxinemia in the fetus may lead to common metabolic disorders. Even in that case, disturbances in the nutritional state cannot account for all the effects of altered thyroid hormone levels on synaptogenesis.

The present results must also be related to our previous morphological and biochemical observations of a delay in thyroid-deficient rats and a temporary acceleration in thyroxine-treated and undernourished ones of the maturation of Bergmann glia cells during the early postnatal period. The development of Bergmann astrocytes occurs very early. Del Cerro and Swarz (1976) have observed Bergmann fibers with typical endfeet leaning against the pia mater in the fetus. In our preparations of the cortex of thyroxine-treated and undernourished neonates compared with controls, these endfeet were more easily recognizable, suggesting that the overall development of Bergmann glia was already accelerated (results not reported). Thus, the developmental troubles of Bergmann astrocytes seem to occur concomitantly with perturbations in neuronal maturation. We do not know to what extent they are due to a direct inflence on glia or are mediated through precocious effects on neurons. In any case, synaptogenesis and the development of glia are sensitive to thyroid hormone levels and to alterations in the nutritional state very early in the course of development, even in a species so immature at birth as the rat in which fetal thyroid only stars to function on day 17 of gestation.

7e Réunion du groupe Développement I.N.R.A., Nouzilly/Tours, 14-15 mai 1981.

Acknowledgements. - The authors are indebted to Mr. F. Caruso and Mrs. C. Aimar for their expert technical assistance. This work was supported by DGRST grant $N^{\circ}$ 77-7-0965 and INSERM grant $N^{\circ}$ 75-1-204-6.

Résumé. Dès la naissance, on note une tendance à la diminution de la densité synaptique dans l'écorce cérébelleuse du Rat rendu hypothyroïdien par le propylthiouracile depuis le $18^{e}$ jour de la gestation. Chez le nouveau-né ayant reçu de la thyroxine in utero, on observe la tendance inverse, et la densité synaptique est significativement plus élevée que chez l'animal traité par l'antithyroïdien. La stimulation de la synaptogenèse est particulièrement nette au niveau de la couche ganglionnaire et est accompagnée d'une accélération de la croissance des terminaisons nerveuses. Chez le nouveau-né de mère sous-alimentée depuis le jour 6 de la gestation, la densité synaptique est significativement plus élevée que la normale et par conséquent supérieure à ce qu'elle est chez l'animal ayant reçu de la thyroxine in utero. Cependant, aucune prolifération anormale de prolongements neuroniques n'est observée. Ces résultats sont à rapprocher des perturbations de la maturation morphologique et biochimique des astrocytes de Bergmann, mises en évidence dans des situations expérimentales comparables. 


\section{References}

CLOS J., LEGRAND Ch., LEGRAND J., 1979. Early effects of undernutrition on the development of cerebellar Bergmann glia cells. Ann. Biol. anim. Bioch. Biophys., 19, 167-172.

CLOS J., LEGRAND Ch., GHANDOUR M. S., 1980a. Effects of undernutrition and thyroid state on early development of butyrylcholinesterase in the rat cerebellum, 331-333. In DI BENEDETTA C., BALAZS R., GOMBOS G., PORCELLATI G., Multidisciplinary approach to brain development, Elsevier/North-Holland, Amsterdam.

CLOS J., LEGRAND Ch., LEGRAND J., 1980b. Effects of thyroid state on the formation and early morphological development of Bergmann glia in the developing rat cerebellum. Develop. Neurosci., 3, 199-208.

DEL CERRO M. P., SNIDER R. S., 1968. Studies on the developing cerebellum. Ultrastructure of the growth cones. J. comp. Neurol., 133, 341-362.

DEL CERRO M. P., SNIDER R. S., 1972. Axo-somatic and axo-dendritic synapses in the cerebellum of the newborn rat. Brain Res., 43, 581-586.

DEL CERRO M. P., SWARZ J. R., 1976. Prenatal development of Bergmann glial fibers in rodent cerebellum. J. Neurocytol., 5, 669-676.

HAJÓS F., PATEL A. J., BALAZS R., 1973. Effects of thyroid deficiency on the synaptic organization of the rat cerebellar cortex. Brain Res., 50, 387-401.

LAUDER J. M., 1978. Effects of early hypo- and hyperthyroidism on development of rat cerebellar cortex. IV. The parallel fibers. Brain Res., 142, 25-39.

LEGRAND Ch., 1969. Influence de l'hypothyroïdisme sur la croissance en longueur et la différenciation histologique du fémur chez le fotus de rat en fin de gestation. Arch. Anat. micr. Morphol. exp., 58, 291-310.

LEGRAND Ch., CLOS J., LEGRAND J., GHANDOUR M. S., LABOURDETTE G., GOMBOS G., VINCENDON G., 1980. S100 protein and astroglial development in the rat cerebellum: effects of thyroid deficiency, hyperthyroidism and undernutrition, 325-327. In DI BENEDETTA C., BALAZS R., GOMBOS G., PORCELATI G., Multidisciplinary approach to brain development. Elsevier/North-Holland, Amsterdam.

REBIĖRE A., 1975. Répercussions précoces de l'hypothyroïdie sur la synaptogenèse dans le cortex cérébelleux du rat nouveau-né. Experientia, 31, 77-80.

VINCENT J., 1981. Répercussions de l'hypothyroïdie et effets correcteurs de la thyroxine sur la maturation ultrastructurale de la couche moléculaire de l'écorce cérébelleuse du jeune rat. Th. Doct. $3^{\text {e }}$ cycle (Endocrinologie), Université des Sciences et Techniques du Languedoc, Montpellier II.

VIGOUROUX E., 1974. Développement de la fonction thyroidienne chez le jeune rat. Th. Doct. ès Sci. Univ. Paris VI.

WEST M. J., DEL CERRO M., 1976. Early formation of synapses in the molecular layer of the fetal rat cerebellum. J. comp. Neurol., 165, 137-160. 